\title{
LAND SUITABILITY EVALUTION FOR CEREAL CROPS: A MULTICRITERIA APPROACH USING GIS AT PARBATIPUR VDC, CHITWAN, NEPAL
}

\author{
B. Neupane ${ }^{1}$, C.P. Shriwastav ${ }^{1}$, S.C. Shah ${ }^{1}$ and K. Sah ${ }^{2}$ \\ ${ }^{1}$ Institute of Agriculture and Animal Sciences, Tribhuvan University, Nepal \\ ${ }^{2}$ Nepal Agriculture Research Council, Kathmandu, Nepal
}

\begin{abstract}
A research was conducted to evaluate the suitability of soils of different land unit for cereal crops productions at Parbatipur VDC, Chitwan, Nepal with the integrated use of Geographical Information system (GIS) and Multi-criteria evaluation (MCE).Existing geodatabase information from National Land Use Project (NLUP) was used as data for this research. The database was used to derive crop suitability using vector based index model in GIS along with multicriteria analysis. The research revealed that for rice cultivation, $1.06 \%(10.70 \mathrm{ha})$ was highly suitable,51.54 $\%(515.89$ ha) was moderately suitable, $3.39 \%$ (33.987 ha) was marginally suitable but $28.28 \%$ ( $283.11 \mathrm{ha}$ ) was not suitable whereas for wheat cultivation, $7.6 \%(76.73 \mathrm{ha})$ was highly suitable, $44.91 \%$ (449.53 ha) was moderately suitable and 4.6\% (46.26ha) was marginally suitable, but $27.15 \%$ (27.14ha) was not suitable. Similarly, for maize cultivation, $12.07 \%$ (120.83ha) was highly suitable, $40.19 \%$ (402.25ha) was moderately suitable and $0.53 \%$ (5.37ha) was marginally suitable, but $31.54 \%$ (315.72ha) was not suitable for maize production. Hence, the area not suitable for rice, wheat and maize must be allocated for alternative uses to achieve optimum productions and further there must be new research for alternative land uses in VDC, where these crops were not suitable for optimum productions.
\end{abstract}

Keywords: Land resources, Geographical information System, Multicriteria evaluation

\section{INTRODUCTION}

Land suitability evaluation is a basis to achieve optimum utilization of the available land resources for sustainable agricultural production. Beek (1978), defined a land evaluation is a process of matching the selected land qualities and comparing them with land use requirements. Complex characters of land also considered as land quality, acts in a specific manner and effect on the suitability of land for a specific kind of use (Kavetskiy et al., 2003). Larson and Pierce, (1991), defined land quality as fitness for use and "the ability of a soil to work" (Karlen et al., 1997).

For improved spatial decision making Multi Criteria Decision Making (MCDM) or Multi Criteria Evaluation (MCE) was developed as more alternatives are evaluated based on conflicting criteria, with the aid of pair-wise comparison matrix (PWCM) and analytical hierarchy process (AHP). For multiple criteria decision-making issues the effective tool is MCE (Malczewski, 2006). Use of GIS and MCE can assist land-use planners to develop decision-making processes (Malczewski,1999). GIS helps in the manipulations of assessment factors and MCE integrates it to a suitability maps. Suitable lands for vegetable crops in Nepal was evaluated by Baniya(2008) and he concluded that MCE with GIS is an important tool for aggregation of socio-economic and environmental data.

In order to enhance the soil fertility and soil water conservation technique, there had been considerable research in Nepal over the years (Keatinge et al., 1999; Acharya et al., 2000). The decline in soil fertility is a major concern for most farmers (Turton et al., 1995). Shrestha et al. (2000) concluded that their adoption of improved techniques had been limited. The productivity of soil had 
been declined due to fertility depletion, imbalance of nutrients in soils, decline into organic matter context, which resulted into reducing physical and chemical properties of soils. So a research was carried out at VDC level at Parbatipur VDC in Chitwan district, Nepal in order to utilize the existing soil resource to achieve the sustainable agricultural production, integrating the MCE and GIS.

\section{Research area}

\section{MATERIAL AND METHODS}

The research was carried out in Parbatipur, VDC of western Chitwan (inner terai) district of central development region.. The VDC covering area is about 1000.19 hectares. Geographically it is located between $27^{\circ} 30^{\prime}$ and $27^{\circ} 35^{\prime}$ North latitude and $83^{\circ} 48^{\prime}$ and $83^{\circ} 51^{\prime}$ East longitude.

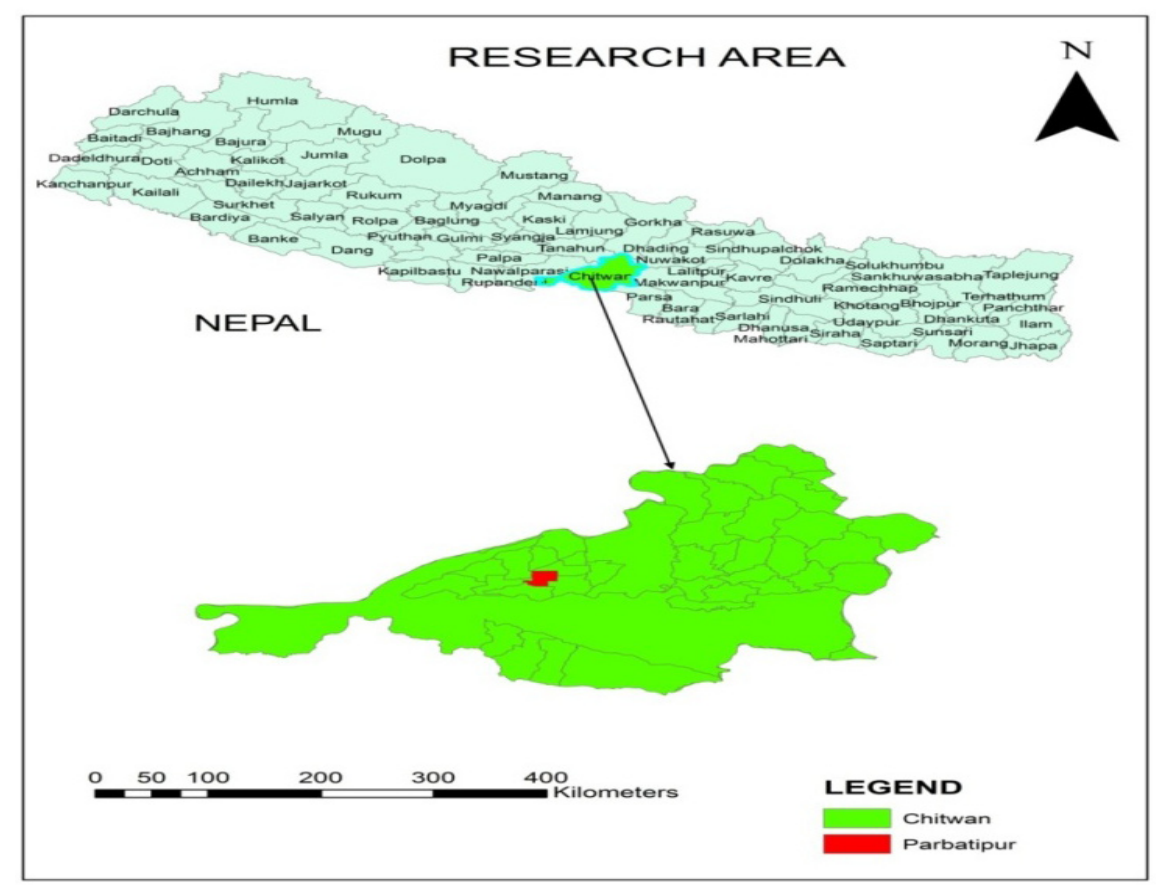

Plate 1. Map of Nepal, Chitwan and Parbatipur VDC

\section{Selection of cereal crops}

Mainly three dominant crops prevalent on these areas were acquired for the research and they were Rice, Maize and Wheat. The cereal crops which were acquired for the research and their classification (Table 1).

Table 1. Cereals crops selected for research

\begin{tabular}{lccc}
\hline Parbatipur VDC (crops) & Scientific name & Nepali name & Family \\
\hline Rice & Oryza sativa & Dhan & Gramineae \\
Wheat & Triticum aestivum & Gahu & Poaceae \\
Maize & Zea mays & Makai & Gramineae \\
\hline
\end{tabular}

\section{Database collection and attributes}

Data sources for VDC were gathered from the Village Development Committee profile, soil attribute data, land use attribute data were gathered from the National Land Use Project (NLUP). 


\section{Preparation of thematic maps}

Using ArcMap software thematic maps were created for each attribute data. Thematic maps include the maps of Land use, Land Capability, and Soil maps.

\section{Classification of criteria acquired in the research}

There were three criteria acquired for the research which are given below.

- Land Capability classification

- Soil

- Land Use

\section{Application of MCE (Multi-criteria evaluation) approach using analytical hierarchy process (AHP)}

Multi criteria evaluation was acquired by applying the various procedure of AHP (Analytical Hierarchy process). Analytical Hierarchy Process, introduced by Satty (1977) was used in decisionmaking, with the assumption that comparison of two elements is derived from their real-time importance. AHP was carried out by following the given steps below.

\section{a. Generation of a hierarchy structure}

AHP technique began with the structuring of the criteria and sub-criteria required for the land suitability and arranging them in a hierarchical form(Table 2).AHP method was applied for three criteria, i.e. Land capability classification, soil and Land use. The final goal of the research was suitability evaluation which occupied at the top most position in the hierarchy. The next level was the main criteria used for the analysis and finally the main criteria were subdivided into sub-criteria.

Table 2. Hierarchical organization for the criteria and sub-criteria acquired in the research

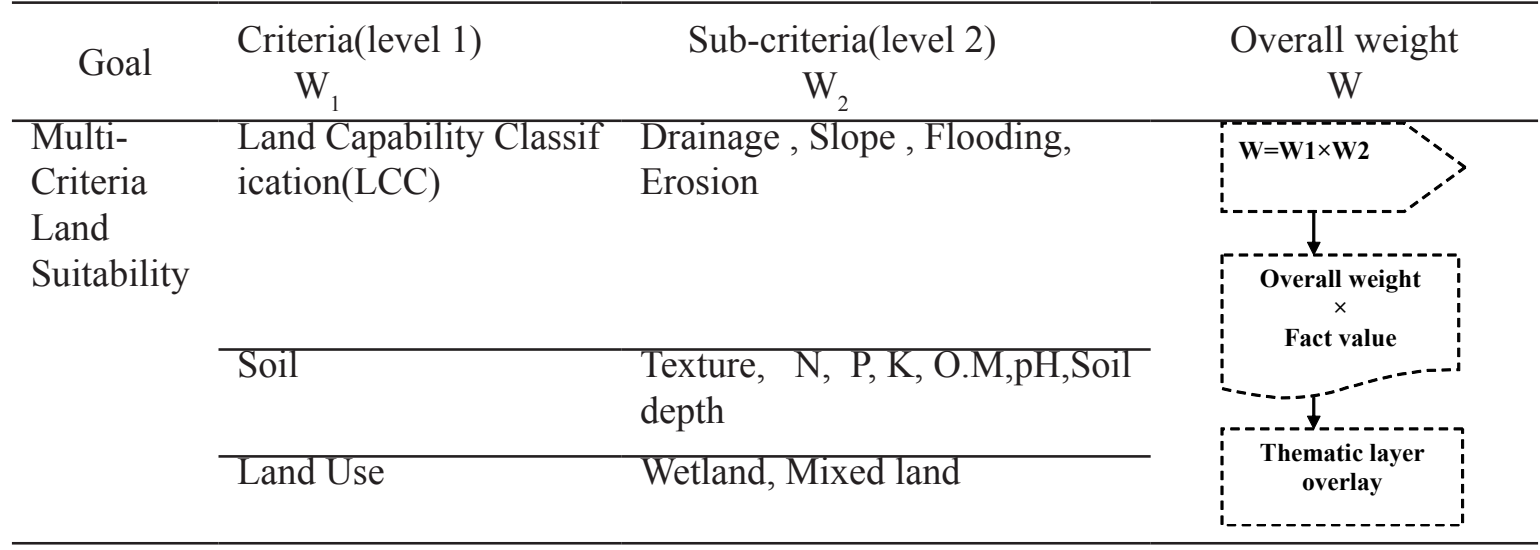

The main criteria are Land Capability Classification, Soil, Land use, The Land Capability Classification was sub-divide into the sub-criteria at level two. Similarly, criteria Soil and Land Use were divided into sub-criteria at level two.

\section{b.Use of pair wise comparison matrix (PWCM)}

The pair-wise comparison matrix (PWCM) was carried out for rating and weighting of the of different sub-criteria and criteria (Table 3). The fundamental scales given by satty's for comparing the two criteria or sub criteria was used. The qualitative value from 1-9 scales was given by ( satty and vargas,2001), considering the comparative importance of two criteria or sub criteria. 
Table 3. Paired-wise comparison for the three criteria

\begin{tabular}{lcccc}
\hline & Criteria 1 & Criteria 2 & Criteria 3 & Weightage \\
\hline Criteria 1 & 1 & $1 / 3$ & 5 & 0.2828 \\
Criteria 2 & 3 & 1 & 7 & 0.6434 \\
Criteria 3 & $1 / 5$ & $1 / 7$ & 1 & 0.0738 \\
\hline$\lambda \max =3.09$ & $\mathrm{CR}=8.3 \%$ & \multicolumn{3}{c}{} \\
\hline
\end{tabular}

Where, $\mathrm{CR}=$ Consistency Ratio, $\lambda \max =$ Principle eigen value

This process of comparing the criteria was carried out for three criteria and their sub-criteria to calculate the weightage (normalized priority vector). Further the process of calculation of consistency ratio was done as given below.

\section{c. Calculation of consistency ratio}

Step 1. Consistency index was calculated,

Consistency index $(\mathrm{CI})=(\lambda \max -\mathrm{n}) /(\mathrm{n}-1)$

Where $\mathrm{n}=$ number of criteria $\quad \lambda$ max $=$ Maximum eigen value

Step 2. Random consistency index (RI) was calculated (Table 4). RI value depends upon the number of criteria or sub-criteria acquired in the research

Table 4. RI value at different number of criteria

\begin{tabular}{lllllllllll}
\hline $\mathrm{N}$ & 1 & 2 & 3 & 4 & 5 & 6 & 7 & 8 & 9 & 10 \\
\hline $\mathrm{RI}$ & 0 & 0 & 0.58 & 0.90 & 1.12 & 1.24 & 1.32 & 1.41 & 1.45 & 1.49 \\
\hline
\end{tabular}

Source: ( Permadi, 1992)

Step 3: Finally, Consistency ratio (CR) was calculated as below

$\mathrm{CR}=\mathrm{CI} / \mathrm{RI}$

Where, $\mathrm{RI}=$ Random consistency, $\mathrm{CI}=$ Consistency index

$\mathrm{CR}$ value $\leq 10 \% \mathrm{AHP}$ is consistent, then further process was done

$\mathrm{CR}$ value $>10 \% \mathrm{AHP}$ is not consistent, revision of process was done

\section{Determination of fact value}

Fact value for each sub-criteria was classified from the 0-9 scales with suitability order (Table 5)

Table 5. Fact value for criteria/sub-criteria

\begin{tabular}{llc}
\hline Fact value & Suitability order & Classification \\
\hline 9 & Highly suitable & S1 \\
7 & Moderately Suitable & S2 \\
5 & Marginally Suitable & S3 \\
1 & Not suitable (Presently) & N1 \\
0 & Not suitable (Permanently) & N2 \\
\hline
\end{tabular}

Use of weighted linear combination method to calculate index value

Fact value of sub-criteria was multiplied with the weight calculated from the PWCM. The weighted linear combination method was use to calculate the index value for following criteria and their sub-criteria

a. Land Capability index

b. Soil rating index

c. Land use index 
For example flood index (sub-criteria of capability index) was calculated as given below:

Flood index $=\sum$ Overall weight $\mathrm{x}$ fact value or score of its sub criteria

Where, Weightage $=$ Normalized eigen vector as calculated in the Table 3 .

Fact value $=$ Fact value of sub-criteria as given in the Table 5 .

\section{Final suitability index}

Final suitability index is calculated in Arc-catalog software with addition of all index. Therefore suitability index =Land Capability index + soil rating index + land use index

\section{GIS modeling}

ArcMap and Arc-catalog software were used in GIS modeling (fig.1). Weighted linear combination method was used to calculate index value of each sub-criteria considering its criteria in the Arc-catalog. Following shape file was created in ARC-GIS software for each crop.
a. Land capability index.shp
b. Soil rating index.shp
c. Land use.shp

GIS model was run in the ArcMap and suitability Map was created for each cereal crops. The flowchart for GIS modeling is given below.

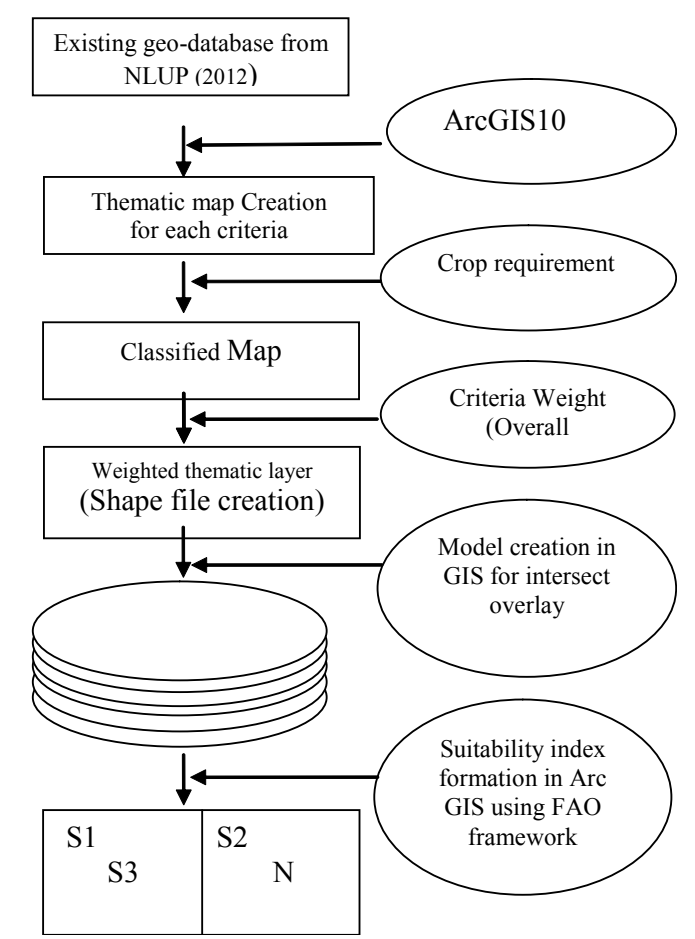

Fig.1 Flowchart showing GIS modeling in ArcMap software.

\section{Suitability evaluation for rice}

\section{RESULTS AND DISCUSSION}

Suitability evaluation for rice in research area revealed that only 10.70 ha $(1.06 \%)$ was highly suitable for rice production, 515.89 ha $(51.54 \%)$ was moderately suitable, and 33.987 ha $(3.39 \%)$ was marginally suitable, while 283.11 ha $(28.28 \%)$ was not suitable for rice cultivation presently. (Table 6). 
Table 6. Suitability area of rice under different classes

\begin{tabular}{clcccc}
\hline Rank & Suitability classes & $\begin{array}{c}\text { Suitability } \\
\text { orders }\end{array}$ & Area (ha) & Area (\%) & Total Area (ha) \\
\hline 0 & Not applicable & - & 155.99 & 15.5 & \\
1 & Highly suitable & S1 & 10.70 & 1.06 & \multirow{2}{*}{1000.8} \\
2 & Moderately suitable & S2 & 515.89 & 51.54 & \\
3 & Marginally suitable & S3 & 33.98 & 3.39 & \\
4 & Not suitable presently & N & 283.11 & 28.28 & \\
\hline
\end{tabular}

Rice suitability of the research area revealed a suitability index value with minimum index value 6.33 and 50 as maximum value. (Table 7)

Table 7. Descriptive statistics for suitability index of rice of the research area

\begin{tabular}{cccccccc}
\hline Count & Minimum & Maximum & Sum & Mean & Median & SD & CV \\
\hline 1042 & 6.33 & 50 & 36997.14 & 35.50 & 50 & 19.64 & $55 \%$ \\
\hline
\end{tabular}

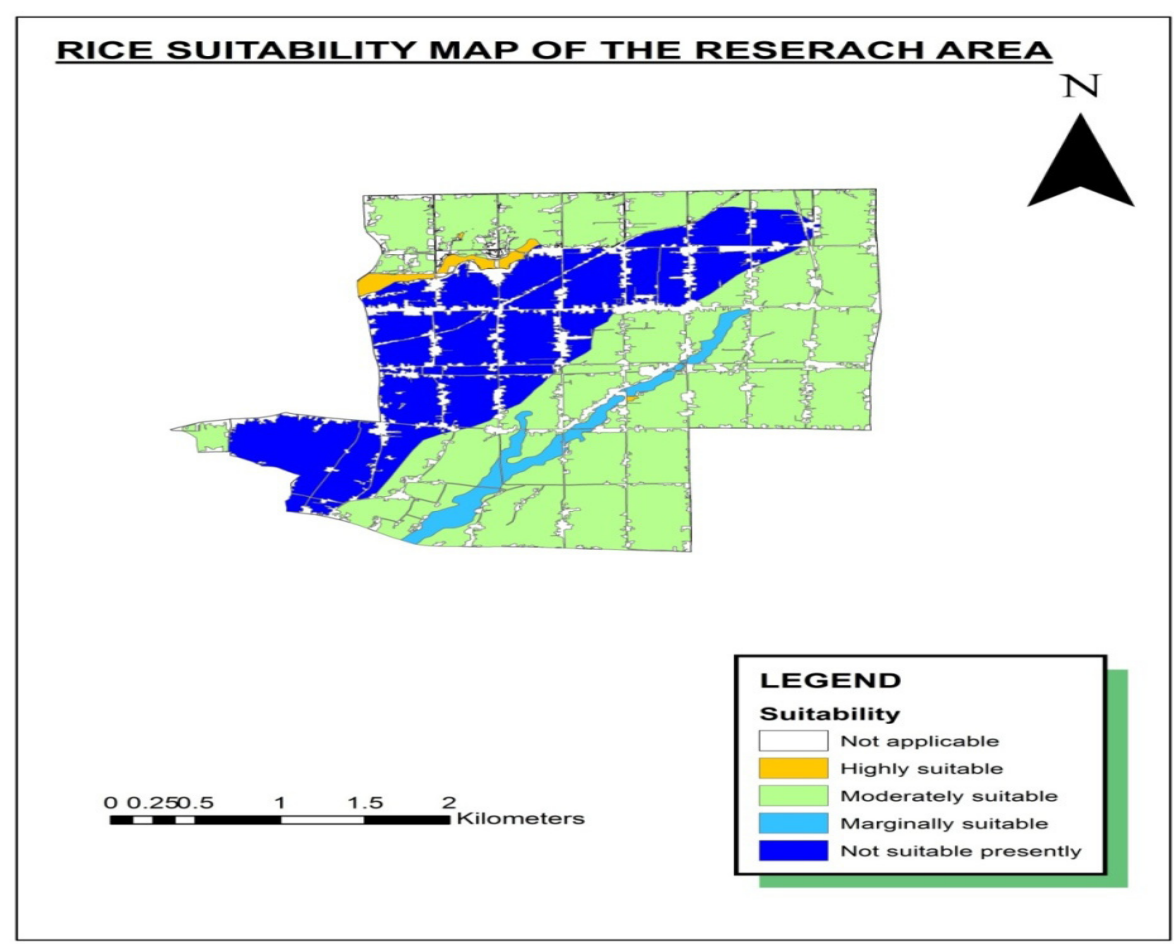

Plate 2. Rice suitability map of the research locale of Parbatipur Village Development Committee, Chitwan, Nepal, 2014

\section{Suitability evaluation for wheat}

Suitability evaluation for wheat in research area revealed that only 76.73 ha (7.6\%) was highly suitable for wheat production, 449.53 ha $(44.91 \%)$ was moderately suitable, and 46.26 ha (4.6\%) was marginally suitable, while 271.65 ha $(27.14 \%)$ was not suitable for wheat cultivation presently. (Table 8) 
Table 8. Suitability area of wheat under different classes

\begin{tabular}{clcccc}
\hline Rank & Suitability & Suitability orders & Area (ha) & Area (\%) & Total area(ha) \\
\hline 0 & Not applicable & - & 155.99 & 15.55 & \\
1 & Highly suitable & S1 & 76.73 & 7.6 & \\
2 & Moderately suitable & S2 & 449.53 & 44.91 & 1000.8 \\
3 & Marginally suitable & S3 & 46.26 & 4.6 & \\
4 & Not suitable presently & N & 271.65 & 27.14 & \\
\hline
\end{tabular}

Wheat suitability of the research area revealed a suitability index with minimum index value 6.33 and 10 as maximum value. (Table 9)

Table 9. Descriptive statistics for suitability index of wheat of the research area

\begin{tabular}{cccccccc}
\hline Count & Minimum & Maximum & Sum & Mean & Median & SD & CV \\
\hline 1042 & 6.37 & 10 & 9371.61 & 8.99 & 10 & 1.38 & 13.85 \\
\hline
\end{tabular}

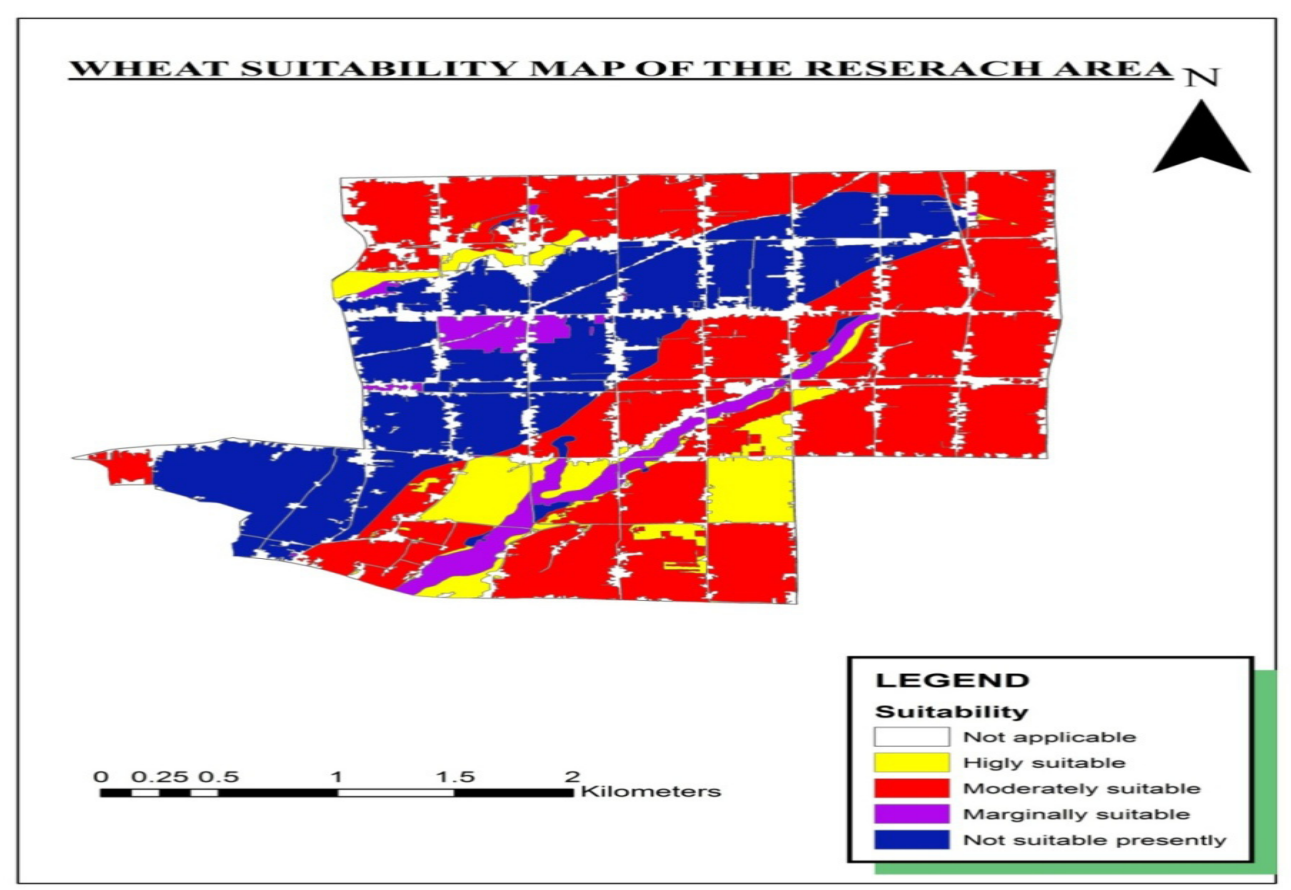

Plate 3. Wheat suitability map of the research locale of Parbatipur Village Development Committee, Chitwan, Nepal, 2014

\section{Suitability evaluation for maize}

Suitability evaluation for Maize in research area revealed that 120.83 ha (12.07\%) was highly suitable, 402.25 ha of area (40.19\%) was moderately suitable, $5.37 \mathrm{ha}(0.53 \%)$ was marginally suitable and 315.72 ha $(31.5 \%)$ was not suitable for maize production presently.( Table 10 ) 
Table 10. Suitability area of Maize under different classes

\begin{tabular}{cclccc}
\hline Rank & Area(ha) & Suitability classes & $\begin{array}{c}\text { Suitability } \\
\text { orders }\end{array}$ & Area (\%) & $\begin{array}{c}\text { Total area } \\
\text { ( ha) }\end{array}$ \\
\hline 0 & 155.99 & Not applicable & - & 15.55 & \\
1 & 120.83 & Highly suitable & $\mathrm{S} 1$ & 12.07 & \\
2 & 402.25 & Moderately suitable & $\mathrm{S} 2$ & 40.19 & 1000.8 \\
3 & 5.37 & Marginally suitable & $\mathrm{S} 3$ & 0.53 & \\
4 & 315.72 & Not suitable presently & $\mathrm{N}$ & 31.54 & \\
\hline
\end{tabular}

Maize suitability of the research area shows that, suitability index with minimum index value 6.34 and 15 as maximum value. (Table 11)

Table 11. Descriptive statistics for suitability index of maize of the research area

\begin{tabular}{cccccccc}
\hline Count & Minimum & Maximum & Sum & Mean & Median & SD & CV \\
\hline 1042 & 6.34 & 15 & 13230.94 & 12.69 & 15 & 3.24 & 25.53 \\
\hline
\end{tabular}

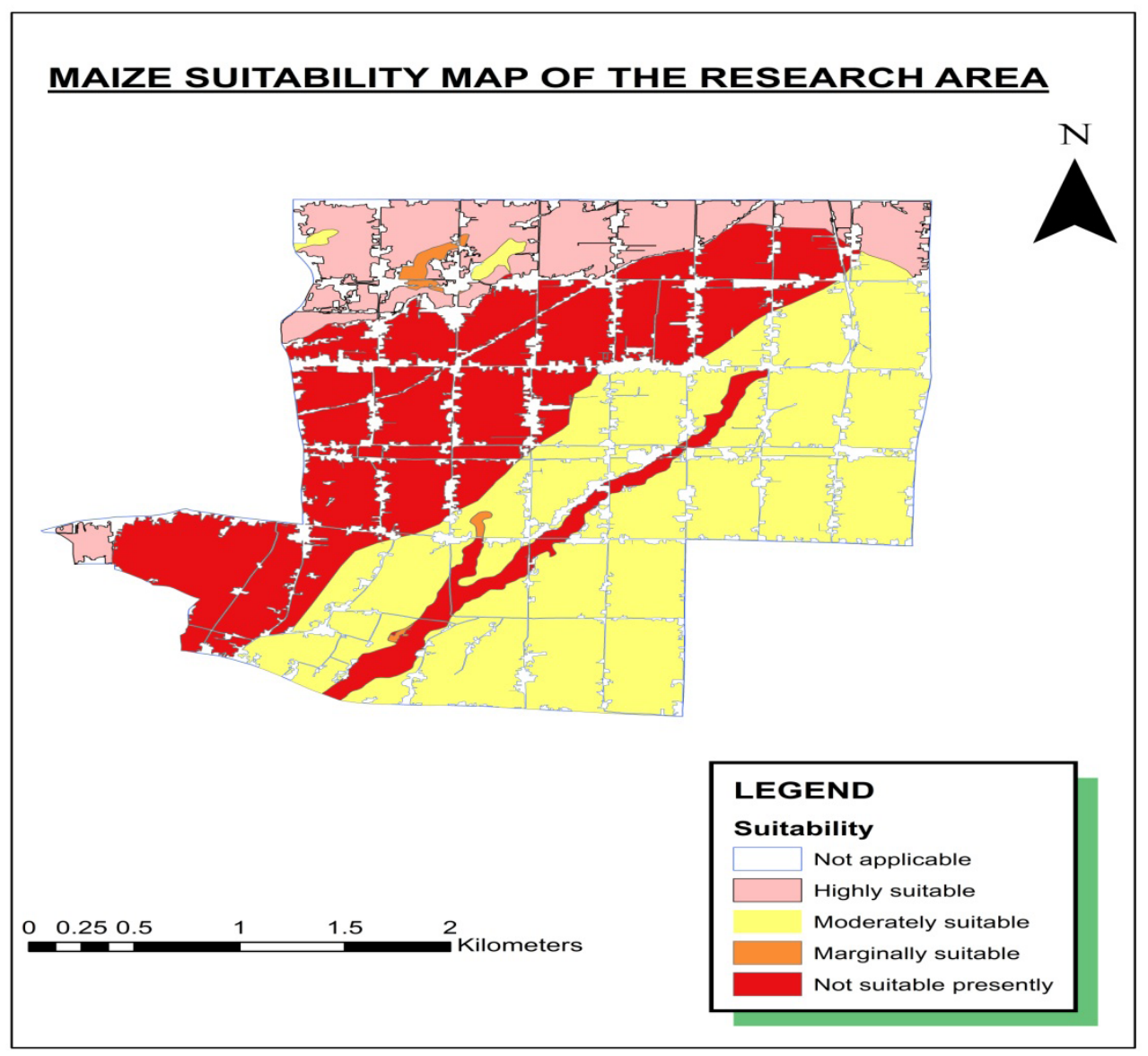

Plate 4. Maize suitability map of the research locale of Parbatipur Village Development Committee, Chitwan, Nepal, 2014 


\section{CONCLUSION}

In this research, integration of MCE and GIS techniques was used to predict suitable areas for cereal crops at VDC level. The outcome obtained from this study indicate that the integration of GIS and MCE could provide a good database and information for planners considering crop substitution to get better agricultural production. This approach had been used in some other countries. However, in Nepal this approach is a new because it has not been used to identify suitable areas for cereal crops.

\section{ACKNOWLEDGEMENT}

Authors are thankful to National Agriculture Research and Development Fund (NARDF) for financial support and National Land Use Project (NLUP) for providing geo-database.

\section{REFERENCES CITED}

Acharya, G.P., B.P. Tripathi, S.P. Shrestha and P.J. Gregory. 2000. Nutrient management in maizefinger millet systems in the hills of Nepal. Lumle Seminar Paper No. 2000/8. Agriculture Research Station Lumle, Pokhara, Nepal.

Baniya, N. 2008. Land suitability evaluation using GIS for vegetable crops in Kathmandu valley, Nepal. Ph.D. thesis submitted to Humboldt University of Berlin.

Beek, K.J. 1978. Land evaluation for agricultural development. Publication 23: 333. (ILRI: Wageningen).

Karlen, D.L., M.J. Mausbach, J.W. Doran, R.G. Cline, R.F. Harris, and G.E. Schuman. 1997. Soil quality: A concept, definition, and framework for evaluation. Soil Sci. Soc. Am. J. 61:4-10

Kavetskiy, S., M. Kraynyuk, G. Hofman, M. Boehme, and O.V. Cleemput. 2003. Soil quality and fertilization. Joint European Project, Tempus Tacis, Kyiv: 5-9 (243p).

Keatinge JDH, Qui A, Wheeler TR, Subedi M, Shah PB, Ellis RH, Summerfield RJ (1999) Annual legume species as green manures/cover crops in low income farming systems of Nepal. Mountain Res. Develop. 19, 325-332p.

Larson, W.E., and J.F. Pierce. 1991. Conservation and enhancement of soil quality. In: Evaluation for sustainable land management in the developing world. International Board Soil Research and Management, Bangkok, Thailand: 115-203.

Malczewski, J. 1999. GIS and Multi-criteria decision analysis. Wiley and Sons Inc., New York, USA.

Malczewski, J, 2006. GIS-based multi-criteria analysis: a survey of the literature. International Journal of Geographic Information Science 20: 703-706

Permadi. 1992. inharited from. Chuong, M. 2007. Multi-criteria Land Suitability evaluation for selected fruit crops in Hilly Region of Central Vietnam. $\mathrm{PhD}$ dissertation submitted to Humboldt University of Berlin, Germany.

Saaty, T.L. 1977. A scaling method for priorities in hierarchical structure: Journal of Mathematical Psychology 15.3: 34-39.

Saaty, T.L. and L.G. Vargas. 2001. Models, methods, concepts \& applications of analytical hierarchy process. International Series in Operations Research and Management sciences. Boston/ Dodrecht/London, Kluwer Academic Publishers. 
Shrestha, B., S.L. Maskey, R.K. Shrestha, B.P. Tripathi, Y.G. Khadka, R.C. Munankarmi, E.M. Bhattari and S.P. Shrestha. 2000. Soil fertility management: farmers' practices and perception in the hills of Nepal. Lumle Technical Paper No. 2000/4. Lumle Agriculture Research Station, Pokhara, Nepal.

Turton, C.N., A. Vaidya, J.K. Tuladhar and K.D. Joshi. 1995. Towards sustainable soil fertility management in the hills of Nepal. Lumle Agricultural Research Center, Nepal/Natural Resources Institute, Chatham Maritime, UK. 